\title{
Peningkatan Kreatifitas dan Hasil Belajar Mahasiswa Dengan Menggunakan Pembelajaran Heuristik Pada Matakuliah Basic Reading
}

\author{
Waliyudin $^{1}$, Ahmadin $^{2}$, Annisah $^{3}$, Umar Sagaf $^{4}$ \\ ${ }^{123}$ STKIP Taman Siswa Bima, \\ ${ }^{4}$ Institut Agama Islam Muhammadiyah Bima \\ Email: waliyudinkhalik@gmail.com, madin_uni15@yahoo.com, annisahnukman@gmail.com, \\ umarsagaf72@gmail.com
}

\begin{abstract}
Abstrak
Penelitian ini bertujuan untuk meningkatkan kreatifitas dan hasil belajar mahasiswa semester II program studi pendidikan bahasa Inggris di STKIP Taman Siswa Bima tahun ajaran 2020/2021 pada mata kuliah basic reading dengan menggunakan strategi Heuristik. Penelitian ini menggunakan metode pre-eksperimental dengan menggunakan one group pretest-posttest. Peneliti sebelumnya memberikan pre-test kepada kelompok yang akan diberikan perlakuan. Kemudian peneliti melakukan perlakuan atau treatment. Setelah selesai perlakuan, peneliti memberikan post-test. Penelitian ini dilakukan di STKIP Taman Siswa Bima, dan yang menjadi sampel adalah mahasiswa Program studi pendidikan Bahasa Inggris semester II yang berjumlah 22 orang mahasiswa yang terdiri dari satu kelas. Pada penelitian ini mahasiswa diberikan pre-test untuk mengetahui pengetahuan, kemampuan awal pada skil basic reading, dan tingkat kreatifitas yang dimiliki oleh mahasiswa. Lalu diberikan treatment berupa pengajaran dengan menggunakan strategi heuristik, setelah itu dilakukan post-test untuk mengetahui peningkatan kreatifitas dan hasil belajar mahasiswa. Adapun hasil penelitian ini menggambarkan bahwa terdapat peningkatan kreatifitas dan hasil belajar mahasiswa setelah melakukan tretmen dengan menggunakan strategi pembelajaran heuristik. Hal ini terlihat dari skor minimum yang didapat oleh mahasiswa dari hasil post-test yaitu 73, sedangkan nilai maksimum 96, sehingga nilai rata-rata yang diperoleh mahasiswa adalah 81,09.
\end{abstract}

Kata Kunci: Kreatifitas, Pembelajaran Heuristik, Reading

\section{PENDAHULUAN}

Basic Reading merupakan matakuliah skill yang harus dikuasai oleh mahasiswa yang mengambil jurusan Pendidikan Bahasa Inggris. Tujuan akhir dari pembelajaran matakuliah ini adalah mahasiswa mampu menguasai secara komprehensif bacaan atau teks yang mereka baca. Penguasaan secara komprehensif ini mencakup pemahaman terhadap isi atau content dan juga pesan atau message yang terdapat dalam teks, sehingga mahasiswa mendapatkan informasi untuk menambah pengetahuan dan pengalaman mereka.

Kemampuan membaca seseorang dinilai dari pemahaman mereka terhadap isi bacaan, kemampuan mereka mendeskripsikan atau menceritakan kembali apa yang telah mereka baca, dan kemampuan memahami pesan yang ada dalam bacaan. Kemampuan-kemampuan ini, jika telah dimiliki oleh seorang pembaca, maka pembaca tersebut dapat dikategorikan sebagai pembaca yang baik atau comphrehensif (Annisah \& Waliyudin. 2017). Namun tujuan capaian pada kemampuan kognitif dan psikomotorik sebaiknya juga diikuti dengan meningkatkan kemampuan pada aspek afektif, seperti kreatifitas mahasiswa.

Secara umum kreatifitas di definisikan sebagai proses dalam memahami sebuah masalah, mencari solusi-solusi yang mungkin, menarik hipotesis, menguji dan mengevaluasi, serta mengkomunikasikan hasilnya kepada orang lain (Intan Syarifah. 2019). Kreatifitas merupakan kemampuan seseorang untuk menciptakan sesuatu yang sama sekali baru atau kombinasi dari karya-karya yang telah ada sebelumnya menjadi suatu karya baru yang dilakukan melalui interaksi dengan lingkungannya untuk menghadapi permasalahan dan mencari alternative pemecahannya melalui cara baru dalam menghadapi suatu masalah atau situasi (Abdul Aziz Saefudin. 2012).

Ciri-ciri kreatifitas terdiri dari: 1) memiliki rasa ingin tahu yang besar; 2) sering mengajukan pertanyaan yang berbobot; 3) memberikan banyak gagasan dan usul; 4) mampu menyatakan pendapat spontan dan tidak malu-malu; 5) memiliki rasa keindahan; 6) 
mempunyai pendapat sendiri dan tidak mudah terpengaruh oleh orang lain; 7) memiliki rasa humor yang tinggi; 8) mempunyai daya imajinasi kuat; 9) mampu mengajukan pemikiran dan gagasan yang berbeda dari orang lain (orisinal); 10) dapat bekerja sendiri; 11) senang mencoba hal-hal baru; 12) dapat mengembangkan suatu gagasan (Wildah, Salwah, Shindy. 2016).

Sedangkan hasil belajar merupakan tujuan yang akan dicapai dari suatu kegiatan pembelajaran. Hasil belajar adalah kemampuankemampuan yang diperoleh setelah melalui kegiatan belajar. Peserta didik yang berhasil dalam belajar adalah peserta didik yang berhasil menguasai kompetensi yang diharapkan. Dari hasil belajar ini pula, seorang pengajar dapat menentukan kedudukan mahasiswanya, apakah termasuk kedalam kategori siswa yang pandai, sedang, atau kurang (Ulin Nafi'ah. 2016).

Pada mata kuliah basic Reading hasil belajar mahasiswa akan diukur melalui pemberian tes berupa tes tertulis, tes lisan, dan praktek membaca. Kemudian, dilakukan pengukuran, penilaian, dan evaluasi pada hasil belajar di ranah cognitif mahasiswa yang meliputi; a) kemampuan mengingat (remember), b) memahami (understand), c) menerapkan (apply), d) menganalisis (analyze), e) mengevaluasi (evaluate), dan f) berkreasi (create) (Claire Wyatt-Smith, J. Joy Cumming. 2009).

Berdasarkan pengalaman peneliti sebagai dosen pengampu matakuliah Basic reading di STKIP Taman Siswa Bima, permasalahan utama yang dihadapi oleh mahasiswa adalah kurang kreatifnya mahasiswa dalam pembelajaran, menyusun kata dan kalimat dalam bahasa Inggris untuk mendeskripsikan pemahaman mereka atas teks yang telah mereka baca, sehingga aspek seperti accuracy, fluency, pronounciation, dan intonation dalam membaca tidak tercapai. Dengan adanya permasalahan-permasalah ini, peneliti sebagai dosen pengampu harus melakukan upaya untuk peningkatan kreatifitas dan hasil belajar mahasiswa, sehingga dapat mengembangkan potensi dan penguasaan skil yang mereka miliki.
Adapun upaya yang diperkirakan dapat meningkatkan kreatifitas dan hasil belajar mahasiswa adalah dengan menggunakan pembelajaran Heuristik. Strategi pembelajaran Heuristik adalah pembelajaran yang dapat memberikan stimulus pada mahasiswa agar aktif dalam pembelajaran, seperti memahami materi, mencari data/fakta, memecahkan masalah dan mempresentasikannya (I made Candiasa. 2017).

Strategi pembelajaran Heuristik sangat cocok diterapkan pada matakuliah Basic Reading, karena mahasiswa akan diberikan stimulus untuk lebih aktif dan kreatif dalam memahami materi atau teks yang mereka baca, sehingga dapat meningkatkan hasil belajar mahasiswa.

Strategi heuristic adalah cara pintas secara kognitif yang menyiapkan secara matang cara pengambilan keputusan yang akurat kepada semua individu di setiap saat. Akal atau cara pintas secara kognitif digunakan untuk melakukan tebakan dari mana harus memulai dan kemana harus melompat agar langkah pemecahan masalah menjadi lebih pendek (Erawati. 2012). Ada empat pendekatan dalam strategi pembelajaran heuristic yang umum digunakan, yaitu; a) model pembelajaran heuristic dengan pendekatan analogi, yaitu pendekatan pembelajaran dengan membandingkan materi yang dipelajari dengan materi lain yang memiliki kesamaan dan sudah dikuasai, b) pendekatan bekerja mundur (working back strategy), adalah pendekatan pemecahan masalah yang dimulai dari tujuan akhir dan selanjutnya bekerja mundur ketujuantujuan sebelumnya yang belum terpecahkan atau tercapai, c) pendekatan memperkecil perbedaan atau dikenal juga dengan hill-climbing, dalam aplikasinya pendekatan ini digunakan untuk menyelesaikan sub-masalah atau sub-tujuan dengan asumsi jika terselesaikan maka akan mengantarkan pada tujuan akhir yang ingin dicapai, dan d) pendekatan memecah tujuan yaitu pendekatan yang dilakukan dengan memecah permasalahan menjadi serangkaian subtujuan, hal ini bertujuan untuk memecahkan masalah menjadi bagian-bagian kecil, sehingga mudah untuk diselesaikan (Jarmila Novotna. 2014). Pada penelitian ini akan diterapkan dua pendekatan saja, yaitu pendekatan bekerja 
mundur untuk penyajian materi, dan pendekatan analogi untuk pelaksanaan latihan.

\section{METODE}

Penelitian ini menggunakan metode preeksperimental dengan menggunakan one group pretest-posttest. Peneliti sebelumnya memberikan pre-test kepada kelompok yang akan diberikan perlakuan. Kemudian peneliti melakukan perlakuan atau treatment. Setelah selesai perlakuan, peneliti memberikan posttest. Penelitian ini dilakukan di STKIP Taman Siswa Bima, dan yang menjadi sampel adalah mahasiswa Program studi pendidikan Bahasa Inggris semester II yang berjumlah 22 orang mahasiswa yang terdiri dari satu kelas. Pada penelitian ini mahasiswa diberikan pre-test untuk mengetahui pengetahuan, kemampuan awal pada skil basic reading, dan tingkat kreatifitas yang dimiliki oleh mahasiswa. Lalu diberikan treatment berupa pengajaran dengan menggunakan strategi heuristik, setelah itu dilakukan post-test untuk mengetahui peningkatan kreatifitas dan hasil belajar mahasiswa. Adapun tahap-tahap yang dilakukan untuk pengumpulan data pada penelitian ini adalah:

1. Tahap persiapan: a) Menyusun instrument pre-test, materi ajar basic reading, kisi-kisi soal, instrument penilaian untuk basic reading, lembar observasi kreatifitas, dan instrument pengukuran hasil belajar mahasiswa. b) Melakukan validasi instrument dengan pakar c) Melakukan uji coba instrument yang telah dibuat d) Menganalisis hasil uji coba instrument untuk mengetahui validitas dan reliabilitasnya

2. Tahap pelaksanaan: a) Melakukan pre-test untuk mengetahui kemampuan awal mahasiswa, dan tingkat kreatifitasnya b) Melakukan treatment dengan mengajar mata kuliah basic reading menggunakan strategi heuristic c) Melakukan observasi pada kreatifitas mahasiswa selama kegiatan pembelajaran dikelas berlangsung Melakukan post-test untuk mengetahui peningkatan kreatifitas dan hasil belajar mahasiswa.

3. Tahap Akhir: a) Mengolah data hasil pre dan post test, dan instrument lainnya
Dilakukan pengujuian hipotesis dengan menggunakan uji-t c) Membandingkan hasil pre dan post test mahasiswa d) Memberikan kesimpulan dan saran berdasarkan hasil yang diperoleh dari penelitian.

\section{HASIL DAN PEMBAHASAN (12pt)}

Tujuan dari penelitian ini adalah untuk meningkatkan kreatifitas dan hasil belajar mahasiswa dengan menhhunakan pembelajaran Heuristik. Hasil pelaksanaan penelitian yang disajikan adalah data hasil analisis pre-test. Pada tabel 1. Adalah data deskripsi dari pre-test yang dilakukan oleh mahasiswa.

1. Data Hasil Analisis Pre-test Mahasiswa

\begin{tabular}{|c|c|c|}
\hline No & Deskripsi & Nilai Pre-test \\
\hline 1 & Nilai Minimum & 42 \\
\hline 2 & Nilai Maksimum & 51 \\
\hline 3 & Rata-rata & 46,22 \\
\hline
\end{tabular}

Berdasarkan hasil analisis pada tabel diketahui bahwa nilai minimum atau skor terendah yang didapatkan oleh mahasiswa pada saat pre-test adalah 42 , nilai maksimum adalah 51, dan nilai rata-rata adalah 46,22, dengan total nomor soal sebanyak 20 nomor. Berdasarkan nilai skor maksimal jika mahasiswa menjawab semua soal dengan benar adalah 100 dengan rentan nilai skor tertinggi untuk tiap butir soal yang benar bernilai 5 .

2. Hasil observasi kreatifitas mahasiswa

\begin{tabular}{|c|c|c|c|}
\hline No & $\begin{array}{c}\text { Ciri-Ciri Kreatifitas pada } \\
\text { siswa }\end{array}$ & Indikator & $\begin{array}{c}\text { Persentase } \\
\text { hasil }\end{array}$ \\
\hline 1 & $\begin{array}{l}\text { Memiliki rasa ingin tahu } \\
\text { yang besar }\end{array}$ & $\begin{array}{l}\text { siswa memperhatikan } \\
\text { penjelasan guru }\end{array}$ & $83,7 \%$ \\
\hline 2 & $\begin{array}{l}\text { Sering mengajukan } \\
\text { pertanyaan yang berbobot }\end{array}$ & $\begin{array}{l}\text { Siswa mengajukan } \\
\text { pertanyaan terkait materi } \\
\text { cerita rakyat Bima yang } \\
\text { dijelaskan oleh guru } \\
\end{array}$ & $85 \%$ \\
\hline 3 & $\begin{array}{l}\text { Memberikan banyak } \\
\text { gagasan dan usul }\end{array}$ & $\begin{array}{l}\text { Siswa meberikan saran } \\
\text { dan ide pada saat diskusi } \\
\text { atau pembelajaran dengan } \\
\text { materi menggunakan } \\
\text { cerita rakyat Bima } \\
\text { berlangsung }\end{array}$ & $59,4 \%$ \\
\hline 4 & $\begin{array}{l}\text { Mampu menyatakan } \\
\text { pendapat spontan dan tidak } \\
\text { malu-malu }\end{array}$ & $\begin{array}{l}\text { Siswa menyatakan } \\
\text { pendapat atas penjelasan } \\
\text { atau jawaban yang } \\
\text { diberikan oleh guru atau } \\
\text { teman kelas lainnya } \\
\text { selama pembelajaran } \\
\text { berlangsung }\end{array}$ & $95 \%$ \\
\hline 5 & Memiliki rasa keindahan & $\begin{array}{l}\text { Siswa mampu } \\
\text { mengemukakan secara } \\
\text { verbal atau tulisan nilai- } \\
\text { nilai yang terkandung } \\
\text { dalam cerita rakyat }\end{array}$ & $83,4 \%$ \\
\hline 6 & $\begin{array}{l}\text { Mempunyai pendapat } \\
\text { sendiri dan tidak mudah } \\
\text { terpengaruh oleh orang lain }\end{array}$ & $\begin{array}{l}\text { Siswa memiliki pendapat } \\
\text { atau pandangan sindiri } \\
\text { ketika berdiskusi atau } \\
\text { pembelajaran dengan } \\
\text { cerita rakyat Bima } \\
\text { berlangsung dan tidak } \\
\text { mudah dipengaruhi oleh }\end{array}$ & $84 \%$ \\
\hline
\end{tabular}




\begin{tabular}{|c|c|c|c|}
\hline & & $\begin{array}{l}\text { pendapat atau pandangan } \\
\text { orang lain, tetap yakin } \\
\text { terhadap jawaban dari } \\
\text { soal atau tugas yang telah } \\
\text { dikerjakan meskipun } \\
\text { banyak kritikan dari orang } \\
\text { lain }\end{array}$ & \\
\hline 7 & $\begin{array}{l}\text { Memiliki rasa humor yang } \\
\text { tinggi }\end{array}$ & $\begin{array}{l}\text { Siswa mengikuti } \\
\text { pembelajaran dengan } \\
\text { santai, }\end{array}$ & $76,7 \%$ \\
\hline 8 & $\begin{array}{l}\text { Mempunyai daya imajinasi } \\
\text { kuat }\end{array}$ & $\begin{array}{l}\text { Siswa menjawab atau } \\
\text { menyelesaikan soal } \\
\text { dengan cara yang berbeda } \\
\text { dari yang dicontohkan } \\
\text { sesuai dengan } \\
\text { imajinasinya, } \\
\text { Mudah melihat kekurang } \\
\text { sempurnaan suatu } \\
\text { penyelesaian atau } \\
\text { jawaban soal }\end{array}$ & $73,3 \%$ \\
\hline 9 & $\begin{array}{l}\text { Mampu mengajukan } \\
\text { pemikiran dan gagasan } \\
\text { yang berbeda dari orang } \\
\text { lain (orisinal) }\end{array}$ & $\begin{array}{l}\text { Siswa dapat menjawab } \\
\text { soal atau tugas secara } \\
\text { verbal atau tertulis yang } \\
\text { berbeda dengan siswa } \\
\text { lainnya }\end{array}$ & $66,7 \%$ \\
\hline 10 & Dapat bekerja sendiri & $\begin{array}{l}\text { Siswa dapat } \\
\text { menyelesaikan soal atau } \\
\text { tugas yang diberikan } \\
\text { secara individu tanpa } \\
\text { bantuan dari orang lain }\end{array}$ & $74,4 \%$ \\
\hline 11 & $\begin{array}{l}\text { Senang mencoba hal-hal } \\
\text { baru }\end{array}$ & $\begin{array}{l}\text { Siswa berani menerima } \\
\text { tugas-tugas yang sulit, } \\
\text { siswa antusias dengan } \\
\text { informasi baru }\end{array}$ & $95 \%$ \\
\hline 12 & $\begin{array}{l}\text { Dapat mengembangkan } \\
\text { suatu gagasan }\end{array}$ & $\begin{array}{l}\text { Siswa dapat } \\
\text { mengembangkan suatu } \\
\text { gagasan atau ide terkait } \\
\text { dengan materi } \\
\text { pembelajaran yang sedang } \\
\text { berlangsung }\end{array}$ & $66,7 \%$ \\
\hline
\end{tabular}

Dari tabel hasil observasi kreatifitas mahasiswa selama kegiatan belajar menggambarkan bahwa mahasiswa semester II Program studi Pendidikan Bahasa Inggris STKIP Taman Siswa Bima Mampu menyatakan pendapat dengan spontan, tidak malu-malu dan senang mencoba hal-hal baru mencapai tingkat persentase tertinggi yaitu $95 \%$ tapi mahasiswa juga sangat lemah dalam memberikan banyak gagasan dan usul persentasenya yaitu 59,4\% . Selain dari ciri dan indikator tersebut mahasiswa juga secara umum memiliki tingkat kreativitas yang baik. Hal ini tergambar pada tabel hasil observasi kreativitas mahasiswa diatas bahwa dengan memiliki kreativitas bisa berimplikasi pada hasil belajar.

3. Hasil Belajar Mahasiswa Menggunakan Pembelajaran Heuristik

\begin{tabular}{|c|c|c|c|c|c|c|c|}
\hline \multirow{2}{*}{ No } & \multirow{2}{*}{ Nama } & \multicolumn{4}{|c|}{ Hasil Belajar Basic Reading Mahasiswa } & \multirow{2}{*}{$\begin{array}{l}\text { Total } \\
\text { Skor }\end{array}$} & \multirow{2}{*}{$\begin{array}{c}\text { Nilai } \\
\text { Rata- } \\
\text { rata }\end{array}$} \\
\hline & & Fluency & $\begin{array}{c}\text { Accurac } \\
\mathbf{y}\end{array}$ & $\begin{array}{c}\text { Pronunciat } \\
\text { ion }\end{array}$ & Intonation & & \\
\hline $\mathbf{1}$ & Hubertus Abal & 380 & 340 & 370 & 380 & 1.470 & 367.5 \\
\hline 2 & $\begin{array}{c}\text { Annisa } \\
\text { Turrahmah }\end{array}$ & 350 & 360 & 370 & 380 & 1.460 & 365 \\
\hline 3 & \begin{tabular}{|c|} 
Dimas Marcel \\
Priyatama
\end{tabular} & 360 & 380 & 370 & 360 & 1.470 & 367.5 \\
\hline 4 & Syafrurrahman & 370 & 360 & 390 & 350 & 1.470 & 367.5 \\
\hline $\mathbf{5}$ & Asri Rahman & 360 & 390 & 370 & 390 & 1.510 & 377.5 \\
\hline 6 & Juniati & 360 & 390 & 370 & 380 & 1.500 & 375 \\
\hline 7 & $\begin{array}{c}\text { Putri } \\
\text { Wulandari }\end{array}$ & 360 & 390 & 400 & 380 & 1.530 & 382.5 \\
\hline
\end{tabular}

\begin{tabular}{|l|c|c|c|c|c|c|c|}
\hline $\mathbf{8}$ & $\begin{array}{c}\text { Zahda } \\
\text { Syauqinah } \\
\text { Firdausa }\end{array}$ & 350 & 370 & 380 & 380 & 1.480 & 370 \\
\hline $\mathbf{9}$ & $\begin{array}{c}\text { Ferbian } \\
\text { Ibrahim }\end{array}$ & 380 & 370 & 390 & 400 & 1.540 & 385 \\
\hline $\mathbf{1 0}$ & Fitri Yani & 360 & 380 & 380 & 390 & 1.510 & 377.5 \\
\hline $\mathbf{1 1}$ & Nani & 370 & 380 & 360 & 380 & 1.490 & 372.5 \\
\hline $\mathbf{1 2}$ & Islamiati & 380 & 370 & 370 & 380 & 1.500 & 375 \\
\hline $\mathbf{1 3}$ & $\begin{array}{c}\text { Amanda } \\
\text { Pratiwiningsih }\end{array}$ & 380 & 380 & 370 & 370 & 1.500 & 375 \\
\hline $\mathbf{1 4}$ & Jul'Asro & 390 & 390 & 380 & 390 & 1.550 & 387.5 \\
\hline $\mathbf{1 5}$ & $\begin{array}{c}\text { Andini } \\
\text { Apriyanti }\end{array}$ & 390 & 390 & 380 & 400 & 1.560 & 390 \\
\hline $\mathbf{1 6}$ & $\begin{array}{c}\text { Rahmatul } \\
\text { Fitriah }\end{array}$ & 370 & 360 & 380 & 380 & 1.490 & 372.5 \\
\hline $\mathbf{1 7}$ & Raodah & 370 & 360 & 380 & 370 & 1.480 & 370 \\
\hline $\mathbf{1 8}$ & M. Maulana & 380 & 360 & 380 & 380 & 1.500 & 375 \\
\hline $\mathbf{1 9}$ & Ma'Ruf & 380 & 380 & 390 & 390 & 1.540 & 385 \\
\hline $\mathbf{2 0}$ & Eka Sri Andika & 370 & 360 & 380 & 380 & 1.490 & 372.5 \\
\hline $\mathbf{2 1}$ & Ahmad & 340 & 340 & 340 & 350 & 1.370 & 342.5 \\
\hline $\mathbf{2 2}$ & M. Hidayat & 390 & 380 & 380 & 380 & 1.530 & 382.5 \\
\hline
\end{tabular}

Pada tabel diatas disajikan analisis hasil belajar mahasiswa dengan menggunakan pembelajaran Heuristic. Pemberian treatment dengan pembelajaran Heuristic dilakukan sebanyak 10 kali pertemuan, sedangkan nilai atau skor mahasiswa diambil pada 5 kali pertemuan dengan menggunakan 5 jenis teks, yaitu narrative, descriptive, recount, instruction, dan opinion teks. Mahasiswa diminta untuk membaca teks lalu tim peneliti memberikan penilaian atau skor berdasarkan 4 komponen penilaian dalam reading yaitu mengukur atau menilai fluency, accuracy, pronounciation, dan intonation mahasiswa ketika membaca.

4. Hasil Analisis Post-test Mahasiswa

\begin{tabular}{|c|c|c|}
\hline No & Deskripsi & Nilai Pre-test \\
\hline 1 & Nilai Minimum & 73 \\
\hline 2 & Nilai Maksimum & 96 \\
\hline 3 & Rata-rata & 81,09 \\
\hline \multicolumn{3}{|c|}{ Berdasarkan hasil analisis pada tabel }
\end{tabular}

Hasil analisi Post-Test diketahui bahwa nilai minimum atau skor terendah yang didapatkan oleh mahasiswa Program studi pendidikan bahasa Inggris STKIP Taman Siswa Bima pada tahap post-test adalah 73 , nilai maksimum adalah 96, dan nilai rata-rata adalah 81,09, dengan total nomor soal sebanyak 20 nomor. Berdasarkan nilai skor maksimal jika mahasiswa menjawab semua soal dengan benar adalah 100 dengan rentan nilai skor tertinggi untuk tiap butir soal yang benar bernilai 5. Dari data post-test ini menggambarkan bahwa terdapat peningkatan kreatvitas dan hasil belajar mahasiswa yang signifikan setelah adanya treetment atau perlakuan yang diberikan peneliti (dosen) dengan menggunakan pembelajaran Heuristik. Proses pembelajaran dengan menggunakan Heuristik ini dilaksanakan selam 
10 kali pertemuan sedangkan untuk mendapatkan skor mahasiswa didapatkan dalam 5 kali pertemuan dengan menggunakan 5 jenis test selama proses pembelajaran berlangsung. Hal ini menunjukkan bahwa pembelajaran dengan menggunakan strategi Heuristik dapat meningkatkan kreativitas dan hasil belajar.

Dari hasil persentase lembar observasi kreativitas juga menggambarkan bahwa rata-rata persentasenya baik, bahkan terdapat 2 ciri dan indikator kreatif yang mencapai $95 \%$ dan hanya 1 ciri dan indikator yang masih berada pada angka 59,4\% . berdasarkan persentase hasil lembar observasi kreativitas tersebut maka persentase tersebut masuk dalam kategori tinggi.

\section{KESIMPULAN
Kreatifitas dan hasil belajara mahasiswa} dapat ditingkatkan melalui penggunaan pembelajaran Heuristik itu terlihat pada Mahasiswa juga sudah; 1) memiliki rasa ingin tahu yang besar; 2) sering mengajukan pertanyaan yang berbobot; 3) memberikan banyak gagasan dan usul; 4) mampu menyatakan pendapat spontan dan tidak malumalu; 5) memiliki rasa keindahan; 6) mempunyai pendapat sendiri dan tidak mudah terpengaruh oleh orang lain; 7) memiliki rasa humor yang tinggi; 8) mempunyai daya imajinasi kuat; 9) mampu mengajukan pemikiran dan gagasan yang berbeda dari orang lain (orisinal); 10) dapat bekerja sendiri; 11) senang mencoba hal-hal baru; 12) dapat mengembangkan suatu gagasan.

\section{SARAN}

Penggunaan pembelajaran Heuristik pada matakuliah Basic Readingharus terus diperkuat.

\section{UCAPAN TERIMA KASIH (12pt)}

Tim peneliti menyampaikan terimakasih dan bangga atas kepercayaan Negara dalam hal ini Kementrian Riset dan Teknologi/Badan Riset Inovasi Nasional, LLDIKTI Wilayah 8, STKIP Taman Siswa Bima yang sudah membantu sehingga penelitian ini terselesaikan dengan baik.

\section{DAFTAR PUSTAKA (12pt)}

Annisah \& Waliyudin. 2017. Penerapan ekstensif reading untuk penggembangan kemampuan membaca mahasiswa semester $\mathrm{V}$ program studi Bhs. Inggris STKIP Taman Siswa BIma 2017/2018. Jurnal pendidikan bahasa, Vol 7. No. 2.

I made Candiasa. 2017. Strategi Heuristik Untuk Meningkatkan Ketahanmalangan Siswa dalam Pembelajaran Matematika. Jurnal Seminar Nasional Riset Inovatif ISBN.

Intan Syarifah. 2019. Pengembangan instrument penilaian untuk mengukur kreatifitas siswa dalam menyelesaikan masalah matematika. Skripsi. UIN Sunan Ampel Surabaya.

Abdul Aziz Saefudin. 2012. Pengembangan kemampuan berpikir kreatif siswa dalam pembelajaran Matematika dengan pendekatan pendidikan matematika realistik. Skripsi. Universitas PGRI Yogyakarta.

Wildah, Salwah, Shindy. (2016). Pengaruh kreatifitas dan minat belajar terhadap hasil belajar matematika siswa. Jurnal. Vol 2, Nomor 1. Diunduh dari journal.uncp.ac.id.

Ulin Nafi'ah. 2016. Efektifitas Penggunaan Metode Eksperimen Terhadap Peningkatan Hasil Belajar Siswa (Psikomotorik dan Kognitif) Pada Pokok Bahasan Cahaya Kelas Kelas VIII SMP Negeri 4 Juwana Tahun Tahun Pelajaran 2015/2016. Skripsi. Universitas Islam Negeri Walisongo Semarang.

Claire Wyatt- Smith, J. Joy Cumming. 2009. Educational Assessment in the 21 Century connecting theory and Practice. Australia: Springer.

Ibnu Nanang A. 2016. Penggembangan Instrument penilaian untuk Reading Skill. Universitas Muhammadiyah Ponorogo.

Waliyudin \& Annisah. 2018. Pre-Questioning Strategy on Reading Comprehension Achievement at the Four Semester of English Program Study STKIP Taman Siswa Bima. Jurnal Pendidikan Bahasa Vol. 8. No. 1.

Erawati. 2012. Penerapan Strategi Heuristik Dalam Pembelajaran Matematika Untuk Meningkatkan Motivasi Belajar Siswa Kelas IV SD Negeri 006 Pasir Sialang Kecamatan Bangkinang Seberang Kabupaten Kampar. Skiripsi.

Jarmila Novotna. 2014. Problem Solving in School Mathematics Based on Heuristic Strategies. ERIES Journal Vol. 7 No. 1 